\title{
Armillaria aotearoa species nova
}

\author{
I. A. $\operatorname{Hood}^{1 *}$ and T. D. Ramsfield ${ }^{1,2}$
}

\begin{abstract}
Background: Three named species of Armillaria are currently recognised as occurring in New Zealand: Armillaria novae-zelandiae (G. Stev.) Herink, A. limonea (G. Stev.) Boesew. and Armillaria hinnulea Kile \& Watling. A fourth species (Armillaria sp. nov.) has been collected in New Zealand over a period of 30 years but has not yet been named.

Methods: Maximum likelihood analysis, using DNA sequence data from the internal transcribed spacer region (ITS) of the ribosomal DNA repeat, DNA sequencing of the elongation factor 1-a gene, cultural pairing studies and morphological examination were undertaken to confirm the novelty of Armillaria sp. nov. as a distinct species.
\end{abstract}

Results: Armillaria sp. nov. is distinguished by the morphology of the fresh basidiocarp, cultural interfertility tests with other Armillaria species and DNA sequence data.

Conclusions: Armillaria sp. nov. is here formally named Armillaria aotearoa.

Keywords: Armillaria aotearoa sp. nov., Armillaria novae-zelandiae, Armillaria limonea, Armillaria hinnulea, Nothofagus species, Taxonomy

\section{Background}

Four species of Armillaria are known in New Zealand: Armillaria novae-zelandiae (G. Stev.) Herink; A. limonea (G. Stev.) Boesew.; Armillaria hinnulea Kile \& Watling; and Armillaria sp. nov. This list excludes Armillaria mellea (Vahl) P. Kumm., which was thought to occur in New Zealand but is no longer recognised as present here (Pennycook 2004). Armillaria novae-zelandiae and A. limonea were described 50 years ago under the genus name Armillariella (Stevenson 1964). Both are morphologically distinctive, pathogenic to introduced and sometimes native trees and shrubs and widely distributed in New Zealand (Gadgil 2005). However, by the 1970s, it was apparent that these were not the only species of Armillaria present in this country (Shaw and Calderon 1977). Armillaria hinnulea was reported in both New Zealand and south-eastern Australia in 1983 (Kile and Watling 1983; Kile 1983). Its known New Zealand distribution is so far restricted to Nothofagus forests in the northwestern quarter of the South Island (Ramsfield et al. 2008). The fourth species (A. sp. nov.) was also collected

\footnotetext{
* Correspondence: Ian.Hood@scionresearch.com

${ }^{1}$ New Zealand Forest Research Institute (Scion), Private Bag 3020, Rotorua

3046, New Zealand

Full list of author information is available at the end of the article
}

in the 1980s, from Nothofagus forests in the central North Island (Hood and Sandberg 1987). Fresh basidiocarps of $A$. sp. nov. are readily distinguished from those of the two common species, A. novae-zelandiae and A. limonea, but it is less easily differentiated from A. hinnulea (Kile and Watling 1983; Ramsfield et al. 2008). Nevertheless, the validity of $A$. sp. nov. has been demonstrated by means of DNA sequencing using the ITS and elongation factor $1-\alpha$ regions (Coetzee et al. 2001; Maphosa et al. 2006; Pildain et al. 2009, 2010; Dodd et al. 2010; Fukami et al. 2010), supported by cultural interfertility testing (Kile and Watling 1988).

Armillaria sp. nov. has remained unnamed for nearly 30 years and as a consequence has been referred to by a growing list of inadequate and sometimes misleading informal designations (Hood 1989, 1992, 2012; Hood et al. 2008; Kile et al. 1994; Ridley 1999; McKenzie et al. 2000; Coetzee et al. 2001; Segedin and Pennycook 2001; Pennycook 2004; Gadgil 2005; Guillaumin and Bérubé 2005; Maphosa et al. 2006; Ramsfield et al. 2008; Power et al. 2008; Pildain et al. 2009, 2010; Dodd et al. 2010; Fukami et al. 2010). This paper formally describes and names this species and provides further confirmation of its distinctive authenticity by presenting the results of additional DNA sequence analyses and cultural pairing studies. 


\section{Methods}

\section{Organisms studied}

Details of single-spore (NZFS 2411, NZFS 2421, NZFS 2425, NZFS 2426 and NZFS 2432) and multispore (NZFS 171 and NZFS 2418) isolates of $A$. sp. nov. (New Zealand Forest Research Institute Culture Collection) used to obtain DNA are shown in Table 1. Also included in Table 1 are particulars of isolates of A. limonea from collection NZFRI-M 5643 and A. novae-zelandiae from collection NZFRI-M 5645 used for comparison purposes. Supplementary ITS sequence data of $A$. sp. nov. and the other three New Zealand Armillaria species were obtained from GenBank (Table 1). Besides the isolates, partial ITS sequence data were generated from two fruitbody collections of putative $A$. sp. nov., one dried (NZFRI-M 5714) and one fresh (NZFRI-M 5810), in order to confirm their identity.

A list of the isolates of New Zealand Armillaria species used for the interfertility cultural pairing studies is presented in Table 2.

\section{Culture}

Isolates of all four Armillaria species were cultured either in liquid $2 \%$ malt extract or on $2 \%$ malt agar plates.

\section{DNA analysis}

DNA was extracted from mycelium harvested from the cultures detailed above. All DNA was extracted using a $2 \times$ CTAB protocol (Sambrook et al. 1987). The ITS region of the ribosomal DNA repeat was amplified using $0.5 \mu \mathrm{M}$ of PCR primers ITS-1F (White et al. 1990) and ITS-4B (Gardes and Bruns 1993) according to the protocol of Ramsfield et al. (2008). The PCR product was purified using the StrataPrep PCR purification kit (Stratagene Inc., La Jolla, CA), and both forward and reverse sequences were generated using BigDye ${ }^{\odot}$ Terminator v3.1 sequencing chemistry (Applied Biosystems, Foster City, CA) and the ITS-1F and ITS-4B primers and then run on the ABI Prism ${ }^{\circ} 3100$ capillary sequencer. The forward and reverse sequences were combined to obtain the full sequence of the ITS repeat. ITS sequence data were deposited in GenBank.

Tissue from fruitbody collections NZFRI-M 5714 and NZFRI-M 5810 was separately frozen and ground in liquid nitrogen, and then DNA was extracted using the $2 \times$ CTAB method outlined above. DNA was then amplified using the PCR primers $\mathrm{A} 1 \mathrm{~F}$ and $\mathrm{A} 2 \mathrm{R}$ and the reaction conditions as outlined in Smith-White et al. (2002). PCR products were purified, and the primers A1F and A2R were used to generate ITS sequence data using BigDye ${ }^{\bullet}$ Terminator v3.1 sequencing chemistry and the ABI Prism $^{\odot} 3100$ capillary sequencer. Partial ITS sequence data from these collections were deposited in GenBank.
The relationship between the ITS sequences obtained for the isolates and existing ITS sequences for the other three species of Armillaria in New Zealand was determined through maximum likelihood analysis. The ITS sequences from NZFRI-M 5714 and NZFRI-M 5810 were 230 and 246 base pairs (bp), respectively, shorter than the other sequences due to partial sequencing of the ITS and were therefore not included in the maximum likelihood analysis. The remaining sequences were trimmed to remove the flanking $18 \mathrm{~S}$ ribosomal RNA (rRNA) and 28S rRNA sequences so that sequences started at 5'-GAGA and finished at TTTATTGNN-3'. Alignment was conducted using ClustalW within MEGA6 (Tamura et al. 2013), gap opening penalty 5; gap extension penalty 1.5 was set for both pairwise and multiple alignments. Following alignment, the relationships between the species were inferred using maximum likelihood analysis with 10,000 bootstrap replications using the Kimura 2-parameter model (Kimura 1980) and Schizophyllum commune Fr. (GenBank accession KJ535691) set as the outgroup. Initial trees for the heuristic search were obtained automatically by applying neighbour-join and BioNJ algorithms to a matrix of pairwise distances estimated using the maximum composite likelihood approach and then selecting the topology with superior log likelihood value. All analyses of ITS data were conducted using MEGA6 (Tamura et al. 2013).

A separate ClustalW analysis was performed that included all ITS sequence data from $A$. sp. nov. that were generated in this study for the maximum likelihood analysis, as well as partial ITS sequence data of NZFRI-M 5714 and NZFRI-M 5810, to confirm the identity of these collections as $A$. sp. nov. through ITS sequence alignment. This analysis was also conducted using MEGA6 (Tamura et al. 2013).

The DNA sequence of partial exon 4, complete exon 5 and partial exon 6 of the elongation factor 1- $\alpha$ gene from isolate NZFS 2425 was generated using the PCR primers EF595F and EF1160R following the protocol of Maphosa et al. (2006) with the primer annealing temperature raised to $58{ }^{\circ} \mathrm{C}$.

\section{Interfertility cultural pairing}

Two interfertility tests were undertaken by pairing six of the haploid, single-spore isolates of the New Zealand Armillaria species listed in Table 2 (two each of $A$. limonea, A. novae-zelandiae and $A$. sp. nov.) with diploid Armillaria species isolates of known or unknown identity obtained from basidiocarp or rhizomorph tissue or from multiple spore drops (also listed in Table 2). A third test was undertaken by pairing between haploid $x$ haploid single-spore isolates of the same or different species (A. hinnulea, A. limonea, A. novae-zelandiae or $A$. sp. nov.) (Anderson et al. 1980; Guillaumin et al. 
Table 1 Collection information for isolates of Armillaria that were used in the DNA analysis

\begin{tabular}{|c|c|c|c|}
\hline Species & $\begin{array}{l}\text { GenBank accession } \\
\text { (with reference) }\end{array}$ & $\begin{array}{l}\text { Culture code and } \\
\text { isolate number }\end{array}$ & Origin $^{b}$ \\
\hline \multirow[t]{8}{*}{ A. hinnulea } & AF329905 & CMW4990 & Single spore, Lake Hochstetter, NZ, decayed stump, May, 1994, GSR (WD). \\
\hline & AF329908 & CMW4983 & Basidiocarp on Nothofagus sp. stump, Australia. \\
\hline & AF394918 & DAR37770 & Sommersby, NSW, Australia. \\
\hline & AF454740 & ATCC66125 & Hastings Cave, Tasmania, Australia, Eucalyptus obliqua. \\
\hline & EU734744 $4^{f}$ & NZFS 2207 & Single spore, Station Creek, Maruia, NZ, Nothofagus, May, 2004, TDR, GSR (BR). \\
\hline & EU734745 & NZFS 2394 & Single spore, Lake Rotoroa, NZ, Nothofagus, May, 2005, TDR, GSR (NN). \\
\hline & EU734746 ${ }^{f}$ & NZFS 2376 & Single spore, Lake Rotoroa, NZ, Nothofagus, May, 2005, TDR, GSR (NN). \\
\hline & EU734747 $7^{f}$ & NZFS 2942 & Australia. \\
\hline \multirow[t]{5}{*}{ A. limonea } & AF329927 & CMW4991 & Single spore, Rotoehu Forest, NZ, Pinus radiata, June 1994, NMS, GSR (BP). \\
\hline & AF329928 & CMW4992 & Single spore, Rotoehu Forest, NZ, P. radiata, June 1994, NMS, GSR (BP). \\
\hline & AF329929c & CMW4678 & Rhizomorph, Tuararangaia Forest, NZ, podocarp-hardwood forest, 1985, IAH, CJS (BP). \\
\hline & AF329930 & CMW4680 & Rhizomorph, Tuararangaia Forest, NZ, podocarp-hardwood forest, 1985, IAH, CJS (BP). \\
\hline & KR063265 & NZFS 2239 & $\begin{array}{l}\text { Single spore, from NZFRI-M 5643, Lake Rotoiti, Nelson Lakes National Park, NZ, Nothofagus } \\
\text { sp. forest, May, 2005, TDR, GSR (BR). }\end{array}$ \\
\hline \multirow{5}{*}{$\begin{array}{l}\text { A. novae- } \\
\text { zelandiae }\end{array}$} & AF329923c & CMW4966 & Australia. \\
\hline & AF329924 & CMW4964 & Basidiocarp on P. radiata, Queensland, Australia, GAK. \\
\hline & AF329925 & NZFS 1856/CMW4986 & Single spore, Kepler Track, Fiordland, NZ, May, 1994, GSR (FD). \\
\hline & AF329926 & CMW4722 & Rhizomorph, Tuararangaia Forest, NZ, podocarp-hardwood forest, 1985, IAH, CJS (BP). \\
\hline & KR063266 ${ }^{9}$ & NZFS 2270 & $\begin{array}{l}\text { Single spore, from NZFRI-M 5645, Fenian Creek walkway, Karamea, NZ, dead wood, } \\
\text { Nothofagus sp. forest, May, 2005, TDR, GSR, (NN). }\end{array}$ \\
\hline \multirow[t]{14}{*}{ A. sp. nov. } & AF329931 ${ }^{\mathrm{C}}$ & \multirow[t]{2}{*}{ NZFS 4055/CMW5597 } & \multirow[t]{2}{*}{ Single spore, southern end Whirinaki Track, NZ, May 1985, IAH (TO). } \\
\hline & DQ435644 & & \\
\hline & AF329932 & \multirow[t]{2}{*}{ NZFS 2221/CMW4994 } & \multirow[t]{2}{*}{ Single spore, Tongariro National Park, NZ, May, 1996, JFG, GSR (TO). } \\
\hline & DQ435643 ${ }^{h}$ & & \\
\hline & AF329933 & CMW4993 & Single spore, Tongariro National Park, NZ, May, 1996, JFG, GSR (TO). \\
\hline & KR063257 & NZFS 171 & Multiple spore, Tongariro National Park, NZ, June, 1984, MM (TO). \\
\hline & KR063258 & NZFS 2411 & Single spore, southern end Whirinaki Track, NZ, May 2005, TDR (TO). \\
\hline & KR0632599 & NZFS 2418 & Multiple spore, southern end Whirinaki Track, NZ, May 2005, TDR (TO). \\
\hline & KR063260 & NZFS 2421 & Single spore, southern end Whirinaki Track, NZ, May 2005, TDR (TO). \\
\hline & KR063261 & \multirow[t]{2}{*}{ NZFS 2425} & \multirow{2}{*}{$\begin{array}{l}\text { Single spore, Te Iringa Track, northern Kaimanawa Range, NZ, Nothofagus sp. forest, } \\
\text { May, 2005, TDR (TO). }\end{array}$} \\
\hline & KU295542 $2^{9}$ & & \\
\hline & KR063262 & NZFS 2426 & $\begin{array}{l}\text { Single spore, Te Iringa Track, northern Kaimanawa Range, NZ, Nothofagus sp. forest, } \\
\text { May, 2005, TDR (TO). }\end{array}$ \\
\hline & KR0632639 & NZFS 2432 & $\begin{array}{l}\text { Single spore, Te Iringa Track, northern Kaimanawa Range, NZ, Nothofagus sp. forest, } \\
\text { May, 2005, TDR (TO). }\end{array}$ \\
\hline & GQ411506 & ICMP 16996 & Craigieburn Range, NZ, Nothofagus solandri var. cliffortioides, BCP (MC). \\
\hline
\end{tabular}

aNZFS: New Zealand Forest Research Institute Culture Collection, Rotorua; ATCC: CSIRO collection of G.A. Kile; CMW: Forestry and Agricultural Biotechnology (FABI) Culture Collection, University of Pretoria, South Africa; DAR: Plant Pathology Herbarium, NSW Agriculture, Agricultural Institute, Orange, New South Wales,

Australia; ICMP: the International Collection of Micro-organisms from Plants, Landcare Research, Auckland, New Zealand

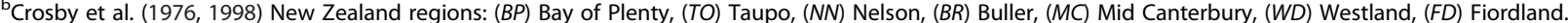

Initials: JFG, J.F. Gardner; IAH, I.A. Hood; GAK, G.A. Kile; BCP, B.C. Paulus; TDR, T.D. Ramsfield; GSR, G.S. Ridley; CJS, C.J. Sandberg; NMS, N.M. Self; MJW,

M.J. Wingfield

'Coetzee et al. (2001)

dSmith-White et al. (2002)

eDunne et al. (2002)

${ }^{f}$ Ramsfield et al. (2008)

${ }^{9}$ This work

${ }^{\mathrm{h}}$ Maphosa et al. (2006)

'Fukami et al. (2010) 
Table 2 Armillaria isolates used in interfertility cultural pairing studies

\begin{tabular}{|c|c|c|c|}
\hline Species & NZFS isolate number ${ }^{a}$ & $\begin{array}{l}\text { Haploid/ } \\
\text { diploid }\end{array}$ & Origin $^{b}$ \\
\hline \multirow[t]{2}{*}{ A. hinnulea ${ }^{c}$} & $\begin{array}{l}2207,2208,2209,2210,2212,2213 \\
2214,2215(57 / 2,3,4,5,7,8,9,10)\end{array}$ & Haploid & Single spores from fruitbody, near Maruia, May 2005, TDR, GSR (BR). \\
\hline & $2391,2392(88 / 1,2)$ & Haploid & Single spores from fruitbody, Lake Rotoroa, near Nelson, May 2005, TDR, GSR (NN) \\
\hline \multirow[t]{2}{*}{ A. limonea ${ }^{d}$} & A31.2 & Haploid & Single spore, Mamaku Plateau near Rotorua, June 1984, IAH, CJS (BP). \\
\hline & A33.1,2, 3934, 3935 (A33.3,5) & Haploid & $\begin{array}{l}\text { Single spores from fruitbody, Mamaku Plateau near Rotorua, June 1984, IAH, CJS } \\
(B P) \text {. }\end{array}$ \\
\hline \multirow{3}{*}{$\begin{array}{l}\text { A. novae- } \\
\text { zelandiae }^{d}\end{array}$} & 3927 (A4.8) & Haploid & Single spore, Mamaku Plateau near Rotorua, May 1982, IAH (BP). \\
\hline & $3928(A 16.1)$ & Haploid & Single spore, Whirinaki Forest Park near Minginui, May 1982, IAH (TO). \\
\hline & $3929,3936(A 20.4,1)$ & Haploid & Single spores from fruitbody, Kaingaroa Forest, June 1982, IAH (BP). \\
\hline \multirow[t]{3}{*}{ A. sp. nov. } & $2425,2426,2427(95 / 1,4,5)$ & Haploid & Single spores from fruitbody, Kaimanawa Forest Park, May 2005, TDR (TO). \\
\hline & $\begin{array}{l}3954,3974,3975,3976,3977,4039,4055 \\
(A 35.5,1,2,3,9,8,4)\end{array}$ & Haploid & Single spores from fruitbody, southern end Whirinaki Track, May 1985, IAH (TO). \\
\hline & Ad35.1,2 & Diploid & Tissue isolates from same fruitbody as NZFS 3954 series. \\
\hline \multirow[t]{3}{*}{ A. species } & Ad34.1,2 & Diploid & $\begin{array}{l}\text { Multiple spore isolates from fruitbody, Tongariro National Park, June 1984, MM } \\
\text { (TO); likely from same collection as NZFS } 171 \text { (Table 1). }\end{array}$ \\
\hline & A223.1 & Diploid & Rhizomorph on decayed wood, Kaimanawa Forest Park, August 1984, IAH (TO). \\
\hline & Mack1985 & Diploid & Multiple spore isolate from fruitbody, Tongariro National Park, 1985, MM (TO). \\
\hline
\end{tabular}

${ }^{a}$ NZFS numbers as held in the New Zealand Forest Research Institute Culture Collection, Rotorua (subsidiary laboratory working numbers are indicated by an alphabetical prefix or incorporated stroke; such isolates not in brackets are no longer extant). Initials: IAH, I.A. Hood; TDR, T.D. Ramsfield; GSR, G.S. Ridley; MM, M. MacKenzie; CJS, C.J. Sandberg

${ }^{\mathrm{b}}$ All isolates from New Zealand. Those of $A$. sp.nov. and A. species from Nothofagus forest; of $A$. novae-zelandiae and A. limonea from podocarp hardwood or Nothofagus forest or from Pinus plantation. Crosby et al. $(1976,1998)$ regions: (BP) Bay of Plenty, (TO) Taupo, (NN) Nelson, (BR) Buller, (WD) Westland

'Identification confirmed using ITS sequencing of representative isolates from these fruitbody collections (Ramsfield et al. 2008)

didentification by fruitbody morphology alone. Table excludes six additional central North Island diploid fruitbody tissue isolates of $A$. limonea and four of A. novae-zelandiae

e Identification confirmed using DNA sequencing of representative isolates NZFS 2425 and NZFS 2426 (this paper), and NZFS 4055 (A35.4; Coetzee et al. 2001 )

1991). The purpose of testing was to use interfertility, firstly, to verify, or otherwise, the uniqueness of $A$. sp. nov. and, secondly, to confirm the unidentified isolates as belonging, or not, to this species through positive or negative interfertility. The haploid test isolates were purposely selected for their appearance in culture (fluffy, of limited rhizomorph growth and coloured white or offwhite with minimal dark pigmentation) to contrast with that of the diploid isolates. Isolates were paired 3-10 mm apart on $2 \%$ malt agar plates and incubated at ambient temperature (ca. $20{ }^{\circ} \mathrm{C}$ ) after sealing around the edge of each plate with a ribbon cut from commercial Glad Wrap ${ }^{\circ}$ plastic transparent film. Interfertility was assessed after 56 weeks. Positive interfertile pairings were indicated by a diploidisation of the haploid isolates denoted by a distinct morphological change with the development of areas of an appressed, dark red-brown or purple, glabrous, spreading crust. Most pairings were duplicated, and one positive replicate was sufficient for the pairing to be judged interfertile. Occasionally, pairings were doubtful. Where this was so in the third, haploid $\times$ haploid test, a small mycelium piece from the junction region between the two isolates was sub-cultured on $2 \%$ malt agar to help clarify the result from its appearance. For a number of selected pairings, the hyphae from this junction region were also examined microscopically after 10 days for the presence of clamp connections (Armillaria sp. nov., eight withinspecies pairings; $A$. hinnulea, 14 within-species pairings; Armillaria sp. nov. $\times$ A. hinnulea, 12 between-species pairings).

\section{Morphological examination}

Dried and fresh fruitbody collections were examined macro- and micro-morphologically in order to provide a more detailed description of $A$. sp. nov. and to compare it with other New Zealand Armillaria species. Sections of fresh or dried gill and cap tissue from a sample of the collections, cut using a freeze microtome after first rehydrating dried material in a humid chamber, were mounted in lactophenol for microscopic examination. To study basidiospores, print deposits were made from two fresh fruitbody collections. One rhizomorph collection was also examined.

\section{Results}

\section{DNA sequence analysis}

The GenBank accession number for each ITS sequence and collection information of every isolate are shown in Table 1. ITS sequence length ranged from a minimum of 677 bp (A. limonea) to a maximum of 
760 bp (A. hinnulea). Within $A$. sp. nov., A. limonea and $A$. hinnulea, the ITS length ranged from 694 to $696 \mathrm{bp}, 677$ to $678 \mathrm{bp}$ and 758 to $760 \mathrm{bp}$, respectively, while within $A$. novae-zelandiae, the ITS sequence length varied from 700 to $739 \mathrm{bp}$. Overall, the maximum likelihood analysis indicated that $A$. sp. nov. had the lowest degree of intraspecific variation, while the analysis showed a higher degree of intraspecific variation within the other three species which had statistically supported sub-clades (Fig. 1).

Minor variation was observed within ITS-1 and ITS-2 regions of the seven isolates from cultures of $A$. sp. nov. that were sequenced in this study. At position 335, a single nucleotide polymorphism was observed; sequences from isolates NZFS 171, NZFS 2418 and NZFS 2425 had A or $\mathrm{G}(=\mathrm{R})$ present, while the others were only A. Four other single nucleotide polymorphisms were noted in the ITS sequence data where one isolate differed from the others: at positions 24 ( $\mathrm{R}$ in NZFS 171), 338 ( $\mathrm{R}$ in NZFS 2425), 408 ( $\mathrm{Y}(=\mathrm{C}$ or $\mathrm{T})$ in NZFS 171) and 621 ( $\mathrm{Y}$ in NZFS 2411). Isolates NZFS 171 and NZFS 2418 were multispore cultures, and it is likely that DNA representing two different nuclei was sequenced.

Maximum likelihood analysis discretely clustered the four species of Armillaria that are present in New Zealand (Fig. 1). Armillaria sp. nov. isolates NZFS 171 (KR063257), NZFS 2411 (KR063258), NZFS 2418 (KR063259), NZFS 2421 (KR063260), NZFS 2425 (KR063261), NZFS 2426 (KR063262) and NZFS 2432 (KR063263) were clearly grouped with each other (shown by their GenBank accession numbers in Fig. 1). These new sequences were also in the same group as existing sequences that were obtained previously from isolates of Armillaria sp. nov. collected in the central North Island of New Zealand in 1985 (NZFS 4055/ CMW5597 (AF329931)) and 1996 (NZFS 2221/

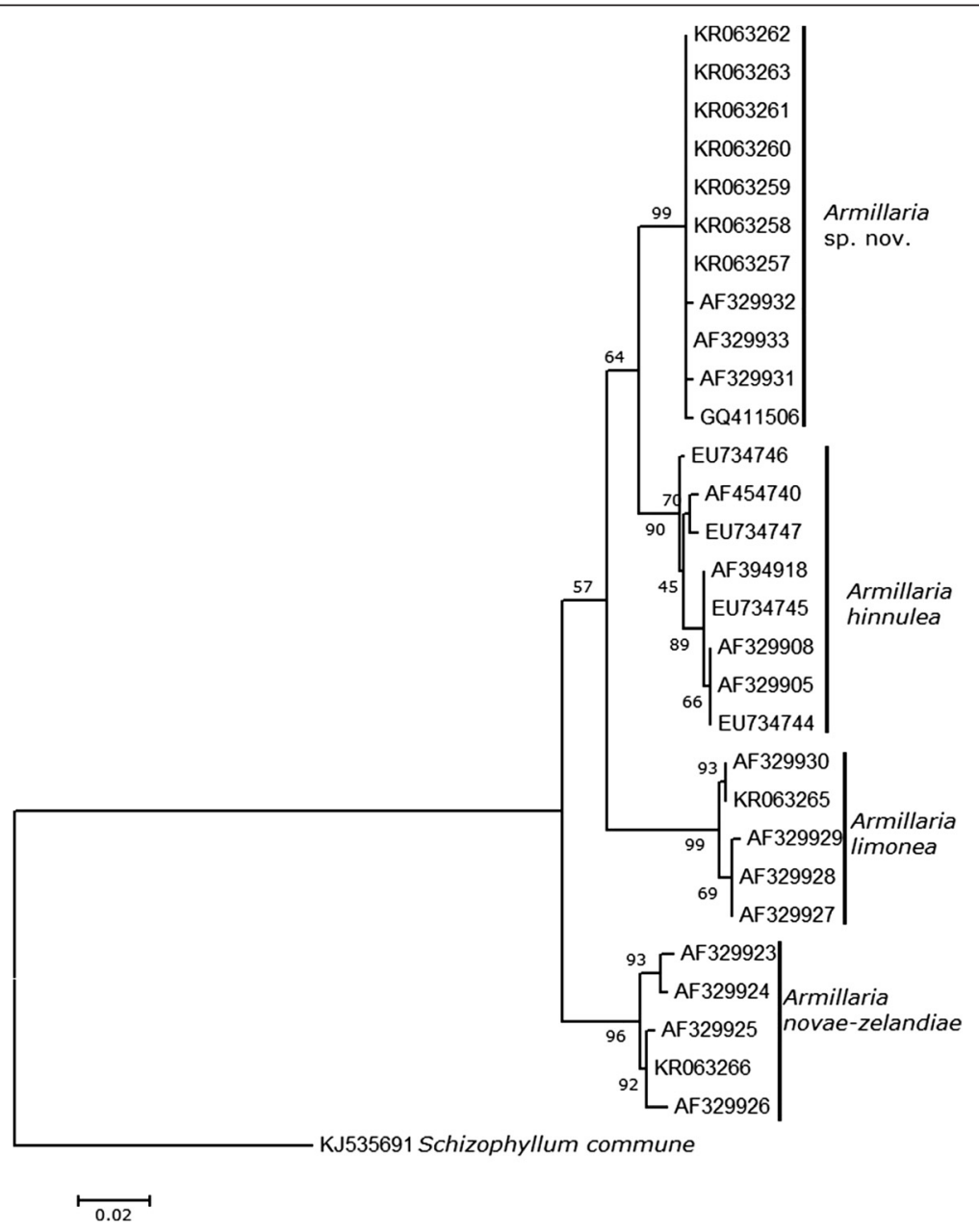

Fig. 1 Maximum likelihood analysis with 10,000 bootstrap replications based on the Kimura 2-parameter model. The tree with the highest log likelihood (-1598.0929) is shown, and the tree is drawn to scale with branch lengths measured in the number of substitutions per site. The percentage of trees in which the associated taxa clustered together is shown next to the branches. There were a total of 530 positions in the final dataset 
CMW4994 (AF329932); CMW4993 (AF329933)) and an isolate that was collected from the South Island in 2006 (IMCP16996 (GQ411506)) (also shown by their GenBank accession numbers in Fig. 1).

Alignment of partial ITS sequences from fruitbody collections NZFR-M 5714 (465 bp) (GenBank KR063264) and NZFRI-M 5810 (449 bp) (GenBank KT336422) with the full ITS data from isolates of $A$. sp. nov. that were sequenced in this study showed minor variation. Over the common $465 \mathrm{bp}$ of the alignment with NZFRI-M 5714, there were differences only at position 35 of the alignment (W instead of $\mathrm{A}$ ) and at position 335 (an A, where 3 isolates were R). Over the common 449 bp of the alignment, NZFRI-M 5810 differed at position $160(\mathrm{H}(\mathrm{H}=\mathrm{A}, \mathrm{C}$ or $\mathrm{T})$ instead of $\mathrm{T})$, at position 172 ( $\mathrm{Y}$ instead of $\mathrm{T}$ ), at position 335 ( $\mathrm{G}$ was present where the isolates were $\mathrm{A}$ or $\mathrm{R}$ ), and at position 408 ( $\mathrm{C}$ was present where the isolates were $\mathrm{T}$ or $\mathrm{Y}$ ). Both of these ITS sequences were generated from DNA extracted from tissue, and it is likely that two nuclear ITS types were sequenced. The sequence alignment, combined with the morphological features of the fruiting bodies, confirmed that these collections represent Armillaria sp. nov.

A total of $584 \mathrm{bp}$ of the partial elongation factor 1- $\alpha$ gene from isolate NZFS 2425 was sequenced and deposited in GenBank under the accession number KU295542. BLAST searching of this DNA sequence resulted in $100 \%$ match (551 bp/551 bp) with GenBank accessions DQ435643 and DQ435644 that originated from isolates of Armillaria sp. nov. collected in the central North Island of New Zealand in 1985 (NZFS4055/CMW5597) and 1996 (NZFS2221/CMW4994), respectively (Table 1).

\section{Cultural pairing}

Results from pairing haploid A. limonea, A. novae-zelandiae or $A$. sp. nov. with diploid Armillaria species isolates are shown in Table 3. The haploid isolates from the A35 series of $A$. sp. nov. (NZFS 4055 and NZFS 3954) were self-interfertile with the Ad35 diploid isolates obtained from the same fruitbody. However, the Ad35 diploid isolates from this set were non-interfertile with haploid isolates of A. novae-zelandiae and A. limonea, confirming the separate nature of $A$. sp. nov. Conversely, six diploid isolates of $A$. limonea and four of A. novaezelandiae generally showed moderate to high interfertility with the haploid isolates of their own species and with no others in both tests (data not included; results for three isolates were unclear or contradictory, but pairings of all isolates with $A$. sp. nov. haploids were negative). The haploid A35 isolates of $A$. sp. nov. were also interfertile with diploid Armillaria species isolates obtained in 1984 and 1985 from basidiocarps collected from Nothofagus solandri var. cliffortioides (Hook. f.)
Table 3 Results from two cultural tests showing interfertilities between pairings of haploid and diploid isolates of different Armillaria species

\begin{tabular}{|c|c|c|c|c|c|c|}
\hline \multirow{5}{*}{$\begin{array}{l}\text { Diploid } \\
\text { isolates } \\
\text { of } A . \text { sp. } \\
\text { nov. }\end{array}$} & \multicolumn{6}{|c|}{ Haploid isolates } \\
\hline & \multicolumn{2}{|c|}{ A. novae-zelandiae } & \multicolumn{2}{|c|}{ A. limonea } & \multicolumn{2}{|c|}{ A. sp. nov. ${ }^{a}$} \\
\hline & \multirow{3}{*}{$\begin{array}{l}\text { NZFS } \\
3927 \\
(A 4.8)\end{array}$} & \multirow{3}{*}{$\begin{array}{l}\text { NZFS } \\
3928 \\
(\text { A16.1) }\end{array}$} & & & \multirow{3}{*}{$\begin{array}{l}\text { NZFS } \\
4055 \\
(A 35.4)\end{array}$} & \multirow{3}{*}{$\begin{array}{l}\text { NZFS } \\
3954 \\
\text { (A35.5) }\end{array}$} \\
\hline & & & & & & \\
\hline & & & $\mathrm{A} 31.2$ & A33.1 & & \\
\hline \multicolumn{7}{|l|}{ Test $1^{\mathrm{b}}$} \\
\hline Ad34.1 & - & - & - & - & $(+)$ & - \\
\hline Ad35.1 & - & - & $(-)$ & - & + & + \\
\hline A223.1 & - & - & - & - & + & $(+)$ \\
\hline Mack1985 & - & - & - & - & + & $(+)$ \\
\hline \multicolumn{7}{|l|}{ Test $2^{c}$} \\
\hline Ad34.2 & - & - & - & - & + & + \\
\hline Ad35.1 & - & - & - & - & + & + \\
\hline Ad35.2 & - & - & - & - & + & + \\
\hline A223.1 & - & - & - & - & + & + \\
\hline \multicolumn{7}{|c|}{ 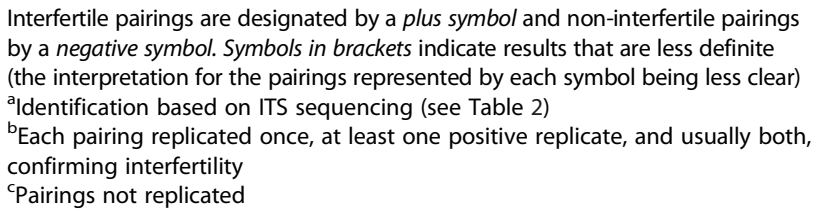 } \\
\hline
\end{tabular}

Poole in Tongariro National Park (Ad34 series and Mack1985; Fig. 2a) and from a rhizomorph of an Armillaria species collected in Kaimanawa Forest Park in 1984 (A223.1), demonstrating that they all likewise belonged to $A$. sp. nov. (Table 3). These diploid isolates of $A$. sp. nov. were also non-interfertile with haploid isolates of A. novae-zelandiae (Fig. 2a) and A. limonea, providing further cultural support for the distinctiveness of A. sp. nov. (Table 3).

The results involving $A$. sp. nov. and $A$. hinnulea in the third test are shown in Tables 4-6. For $A$. sp. nov., 8 of 45 within-species haploid pairings (18\%; excluding self-pairings; Table 4; Fig. 2b) were judged to be interfertile and for $A$. hinnulea, the equivalent respective values were 11 of 41 pairings (27\% interfertile; Table 5). Clamp connections were observed in two within-species pairings of $A$. hinnulea (Table 5). When haploids of both species were paired against each other, there were no interfertile matings (Table 6). Likewise, all haploids of both species were non-interfertile with haploids of $A$. novae-zelandiae (NZFS 3929, NZFS 3936) and A. limonea (NZFS 3934, NZFS 3935; data not included).

\section{Taxonomy}

Armillaria aotearoa Hood and Ramsfield sp. nov. (Fig. 3). 

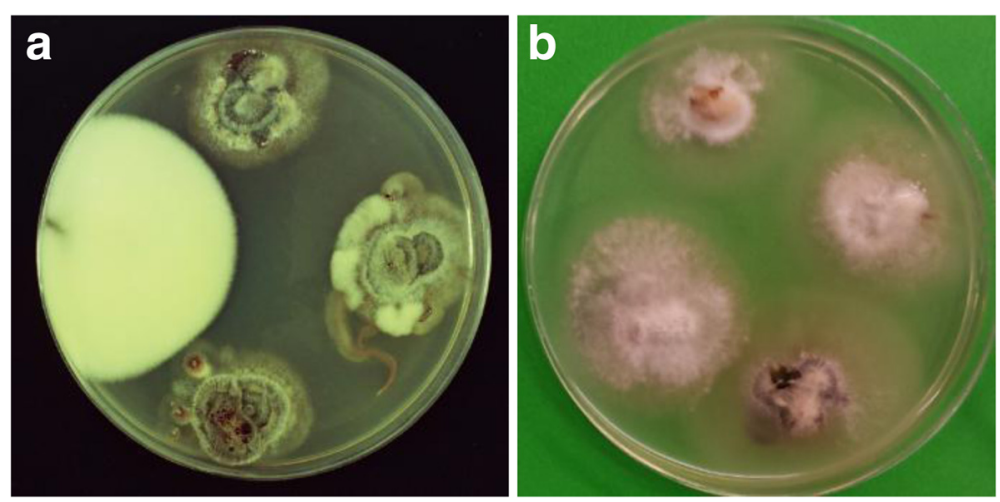

Fig. 2 Cultural pairing tests. a Pairing of multiple spore diploid isolate, Mack1985, with itself (top), two haploid A35 isolates of Armillaria sp. nov. (right and bottom) and a haploid A4 A. novae-zelandiae isolate (left); the A. novae-zelandiae isolate has remained white and fluffy indicating non-interfertility, while the change in appearance to dark and appressed-crustose of the two A35 isolates denotes interfertility with isolate Mack1985, signifying that it also belongs to Armillaria sp. nov. (Scion CN 18632). b Pairing of haploid isolate NZFS 2427 of Armillaria sp. nov. with haploid isolates NZFS $3974-3977$ from a different collection of the same species; that with NZFS 3975 is interfertile (bottom). In both images, the plate is $90 \mathrm{~mm}$ in diameter

Etymology: From 'Aotearoa', contemporary Maori for 'New Zealand'.

Basidiomata pileate, centrally stipitate, caespitose. Pileus 35-60 $\mathrm{mm}$ in diameter, pinkish brown-to-brown, moderately smooth, sprinkled more or less evenly (slightly more dense at centre) with tiny, dark, granular scales, convex at first, becoming plano-convex, dry, commonly with a broad, sharply demarcated hygrophanous (but not viscid) zone around the cap perimeter, not striate or with faint striae only at the margin; flesh offwhite to pale pink. Gills adnexed, moderately crowded, pale pink. Stipe $35-90 \mathrm{~mm}$ long, with a bulbous base, pale pinkish brown, sometimes with a faint greenish or yellowish tinge, dry, fibrillose, with tiny scattered tufts, becoming hollow; flesh off-white to pale pink. Veil forming a persistent annulus, dry, lower surface concolorous with stipe with dark flecks concentrically arranged. Rhizomorphs black, with unevenly dichotomous branching. Gill trama divergent, with a wide, sub-parallel mediostratum of inflated (3-12 $\mu \mathrm{m}$ wide), densely packed hyphae, cells thick-walled (to $1 \mu \mathrm{m}$ ), thin-walled at mediostratum periphery; and narrow lateral strata of more open narrow hyphae $(1-1.5(-4) \mu \mathrm{m}$ wide) diverging towards the subhymenium; clamp connections not seen in trama or subhymenium. Cystidia not observed. Basidia clavate-cylindric, 4-spored, 31-49 × 5-9.5 $\mu \mathrm{m}$, mostly thin-, some thick-walled $(0.9 \mu \mathrm{m})$, without a basal clamp connection, sterigmata to $6 \mu \mathrm{m}$ long. Basidiospores ellipsoid to ovoid, with pronounced apiculus, and in some a prominent vacuole, hyaline, non-amyloid, with smooth walls thin to moderately thick (to $0.8 \mu \mathrm{m}$ ), (7-)7.5$9.5(-10.5) \times 5-7(-7.5) \mu \mathrm{m}$ (excluding apiculus); spore

Table 4 Results from the third cultural test showing interfertilities between pairings of haploid isolates of Armillaria sp. nov. (within-species pairing)

\begin{tabular}{|c|c|c|c|c|c|c|c|c|c|c|c|}
\hline \multirow{2}{*}{$\begin{array}{l}\text { Fruitbody } \\
\text { collection }\end{array}$} & \multirow[t]{2}{*}{ Isolate } & \multirow{2}{*}{$\begin{array}{l}3954 \\
\text { (A35.5) }\end{array}$} & \multirow{2}{*}{$\begin{array}{l}3974 \\
\text { (A35.1) }\end{array}$} & \multirow{2}{*}{$\begin{array}{l}3975 \\
\text { (A35.2) }\end{array}$} & \multirow{2}{*}{$\begin{array}{l}3976 \\
\text { (A35.3) }\end{array}$} & \multirow{2}{*}{$\begin{array}{l}3977 \\
\text { (A35.9) }\end{array}$} & \multirow{2}{*}{$\begin{array}{l}4039 \\
\text { (A35.8) }\end{array}$} & \multirow{2}{*}{$\begin{array}{l}4055 \\
\text { (A35.4) }\end{array}$} & \multirow{2}{*}{$\begin{array}{l}2425 \\
(95 / 1) \\
\end{array}$} & \multirow{2}{*}{$\begin{array}{l}2426 \\
(95 / 40) \\
\end{array}$} & \multirow{2}{*}{$\begin{array}{r}2427 \\
(95 / 5 \\
\end{array}$} \\
\hline & & & & & & & & & & & \\
\hline \multirow[t]{7}{*}{ NZFRI-M 3065} & 3954 & - & & & & & & & & & \\
\hline & 3974 & - & - & & & & & & & & \\
\hline & 3975 & - & - & - & & & & & & & \\
\hline & 3976 & - & - & - & - & & & & & & \\
\hline & 3977 & - & - & - & - & - & & & & & \\
\hline & 4039 & - & - & - & - & - & - & & & & \\
\hline & 4055 & - & - & - & - & - & - & - & & & \\
\hline \multirow[t]{3}{*}{ NZFRI-M 5283} & 2425 & - & $(+)$ & - & + & - & + & - & - & & \\
\hline & 2426 & - & + & - & + & - & - & - & + & - & \\
\hline & 2427 & - & - & $(+)$ & - & - & - & $(+)$ & - & - & - \\
\hline
\end{tabular}

An interfertile pairing is designated by a plus symbol and a non-interfertile pairing by a negative symbol; symbols in brackets indicate results that are less definite (the interpretation for the pairings represented by each symbol being less clear). All pairings replicated once, mostly successfully, but occasional failures of both replicates denoted by gaps (one or both isolates in each replicate did not grow or became contaminated). At least one positive replicate, and usually both, confirmed interfertility. For Armillaria sp. nov., identification is based on ITS sequencing (see Table 2) 
Table 5 Results from the third cultural test showing interfertilities between pairings of haploid isolates of Armillaria hinnulea (within-species pairing)

\begin{tabular}{|c|c|c|c|c|c|c|c|c|c|c|c|}
\hline $\begin{array}{l}\text { Fruitbody } \\
\text { collection }\end{array}$ & Isolate & $\begin{array}{l}2207 \\
(57 / 2)\end{array}$ & $\begin{array}{l}2208 \\
(57 / 3)\end{array}$ & $\begin{array}{l}2209 \\
(57 / 4)\end{array}$ & $\begin{array}{l}2210 \\
(57 / 5)\end{array}$ & $\begin{array}{l}2212 \\
(57 / 7)\end{array}$ & $\begin{array}{l}2213 \\
(57 / 8)\end{array}$ & $\begin{array}{l}2214 \\
(57 / 9)\end{array}$ & $\begin{array}{l}2215 \\
(57 / 10)\end{array}$ & $\begin{array}{l}2391 \\
(88 / 1)\end{array}$ & $\begin{array}{l}2392 \\
(88 / 2)\end{array}$ \\
\hline \multirow[t]{8}{*}{ Not named } & 2207 & - & & & & & & & & & \\
\hline & 2208 & $(+/-)^{a}$ & - & & & & & & & & \\
\hline & 2209 & - & - & - & & & & & & & \\
\hline & 2210 & - & - & $(-)$ & - & & & & & & \\
\hline & 2212 & - & $(+)$ & - & $t^{a}$ & - & & & & & \\
\hline & 2213 & $(+)$ & - & - & + & - & - & & & & \\
\hline & 2214 & - & - & - & $(+)$ & - & - & - & & & \\
\hline & 2215 & - & - & - & $(+)$ & $(+)$ & - & - & - & & \\
\hline \multirow[t]{2}{*}{ NZFRI-M 5682} & 2391 & + & - & - & - & & & & & & \\
\hline & 2392 & $(+)$ & - & - & $(+)$ & - & - & - & - & - & - \\
\hline
\end{tabular}

An interfertile pairing is designated by a plus symbol and a non-interfertile pairing by a negative symbol; symbols in brackets indicate results that are less definite (the interpretation for the pairings represented by each symbol being less clear). All pairings replicated once, mostly successfully, but occasional failures of both replicates denoted by gaps (one or both isolates in each replicate did not grow or became contaminated). At least one positive replicate, and usually both, confirmed interfertility

andicates the observation of a clamp connection

print white. Pileipellis a firm, compact layer ca. $200 \mu \mathrm{m}$ thick, in two levels, each composed of sub-parallel, radially oriented, periclinal hyphae of inflated, thin-(to occasionally firm-) walled cells $(16-109 \times 8-26 \mu \mathrm{m})$ lacking clamp connections; hyphae in upper level $(60-100 \mu \mathrm{m}$ deep) coloured brown, occasionally projecting somewhat above; hyphae in lower level hyaline, merging gradually with pileus tramal hyphae beneath. Pileus trama a soft tissue of looser interwoven, hyaline hyphae lacking clamp connections, constructed of cylindrical to inflated, thin-walled cells $(41-114 \times 8-26 \mu \mathrm{m})$.
Habitat: In Nothofagus forests, on woody debris of Nothofagus fusca (Hook.f.) Oerst., N. menziesii (Hook.f.) Oerst., $N$. solandri var. cliffortioides.

Holotype: NZFRI-M 5283: on dead stem of fallen Nothofagus sp., lower end of Te Iringa Track, Clements Mill Road, northern Kaimanawa Range, Taupo region, 17 May 2005, T.D. Ramsfield (Lat. $38^{\circ} 57^{\prime} 26^{\prime \prime}$ S Long. $176^{\circ} 13^{\prime}$ $\left.17^{\prime \prime} \mathrm{E}\right)$; isolates from NZFRI-M 5283: NZFS 2425-2430, GenBank KR063261, KU295542 (from NZFS 2425), KR063262 (from NZFS 2426). MycoBank registration identifier: MB 815529.

Table 6 Results from the third cultural test showing interfertilities between pairings of haploid isolates of Armillaria sp. nov. $\times$ A. hinnulea (between species pairing)

\begin{tabular}{|c|c|c|c|c|c|c|c|c|c|c|c|}
\hline Fruitbody collection & Isolate & 2207 & 2208 & 2209 & 2210 & 2212 & 2213 & 2214 & 2215 & 2391 & 2392 \\
\hline \multirow[t]{7}{*}{ NZFRI-M 3065} & 3954 & - & - & - & - & - & - & - & - & & - \\
\hline & 3974 & - & - & - & - & - & - & - & - & - & - \\
\hline & 3975 & - & - & - & - & - & - & - & - & - & - \\
\hline & 3976 & - & - & - & - & - & - & - & - & - & - \\
\hline & 3977 & - & - & - & - & - & - & - & - & - & - \\
\hline & 4039 & & - & - & - & & - & - & - & - & - \\
\hline & 4055 & & - & - & - & - & - & - & - & - & - \\
\hline \multirow[t]{3}{*}{ NZFRI-M 5283} & 2425 & - & - & - & - & - & - & - & - & - & - \\
\hline & 2426 & - & - & - & - & - & - & - & - & - & \\
\hline & 2427 & - & - & - & - & - & - & - & - & - & - \\
\hline
\end{tabular}

An interfertile pairing is designated by a plus symbol and a non-interfertile pairing by a negative symbol. All pairings replicated once, mostly successfully, but occasional failures of both replicates denoted by gaps (one or both isolates in each replicate did not grow or became contaminated). At least one positive replicate, and usually both, confirmed interfertility 

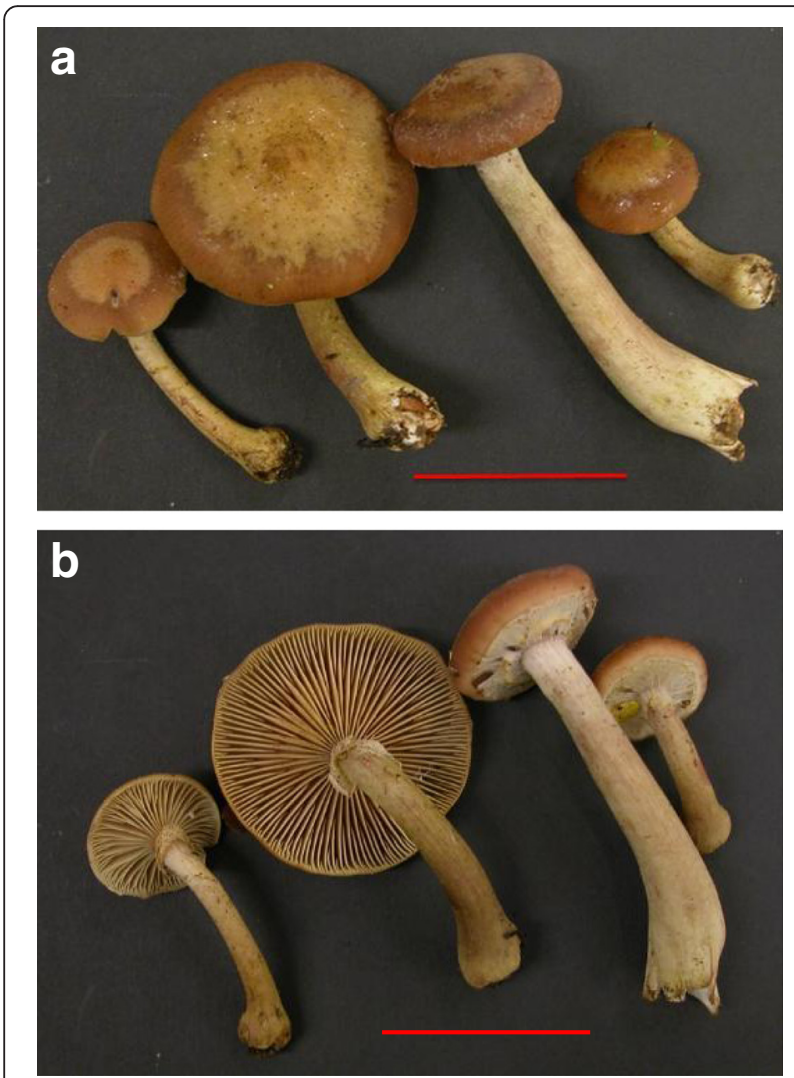

Fig. 3 a Upper and $\mathbf{b}$ lower views of fresh fruitbody collection of Armillaria aotearoa. Lower end of Te Iringa Track, Clements Mill Road, northern Kaimanawa Range, New Zealand, 17 May 2005 (NZFRI-M 5283, holotype). In both images, the bar length is $50 \mathrm{~mm}$

Other collections: NZFRI-M 3065: on fallen log, Nothofagus fusca, southern end of Whirinaki Track near Plateau Hut, Taupo region, 31 May 1985, I.A. Hood (Lat. $38^{\circ} 49^{\prime} 01^{\prime \prime} \mathrm{S}$ Long. $176^{\circ} 38^{\prime} 35^{\prime \prime} \mathrm{E}$; now in poor condition); yielding isolates NZFS 3954, 3974-3977, 4039, 4055, GenBank AF329931 (Table 2). NZFRI-M 5280: on dead stem fallen Nothofagus sp., same location as NZFRI-M 3065, 17 May 2005, T.D. Ramsfield; yielding isolates NZFS 2410-2417, GenBank KR063258. NZFRI-M 5281: on dead stem fallen Nothofagus sp., same location as NZFRI-M 3065, 17 May 2005, T.D. Ramsfield; yielding isolates NZFS 2418, 2419, GenBank KR063259. NZFRIM 5282: on dead stem fallen Nothofagus sp., same location as NZFRI-M 3065, 17 May 2005, T.D. Ramsfield; yielding isolates NZFS 2420-2424, GenBank KR063260. NZFRI-M 5284: on dead stem, fallen Nothofagus sp., same location as holotype, 17 May 2005, T.D. Ramsfield; yielding isolates NZFS 2431-2437, GenBank KR063263. NZFRI-M 5714: on same fallen log as NZFRI-M 3065, 28 April 1988, I.A. Hood, GenBank KR063264 (Fig. 4). NZFRI-M 5810: on uprooted, decaying fallen tree (probably N. solandri var. cliffortioides), $350 \mathrm{~m} \mathrm{NW}$ by $\mathrm{N}$ of Chateau Tongariro, Tongariro National Park, 31

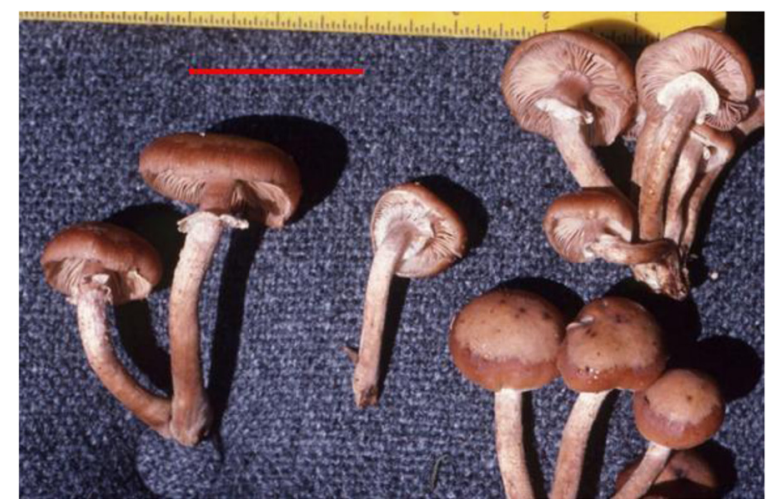

Fig. 4 Fresh fruitbody collection of Armillaria aotearoa. Upper Whirinaki catchment, 28 April 1988 (NZFRI-M 5714; Scion image library PP:0201;050654). The bar length is $50 \mathrm{~mm}$

May 2015, I.A. Hood (Lat. 39¹1'51' 'S Long. 17532'12' 'E); yielding isolates NZFS 4157-4168, GenBank KT336422. Additional culture: NZFS 171: multiple spore isolate from fruitbody on decayed log (probably N. solandri var. cliffortioides), Whakapapaiti track, Tongariro National Park, 13 June 1984, M. MacKenzie (Lat. 39¹3'S Long. $175^{\circ} 31^{\prime} \mathrm{E}$; parent fruitbody, NZFRI-M 2069, no longer exists), GenBank KR063257.

Distribution: Taupo region, Mid Canterbury region (Crosby et al. 1976, 1998).

Description has been expanded from that of Gadgil (2005). Armillaria aotearoa is figured as Armillaria sp. in Hood (1992, Fig. 130). Fruiting is observed between late April and mid-June. Fresh basidiocarps are smaller than those of $A$. limonea which differ in the whitish to markedly yellowish hues on the cap and upper stipe. Fructifications of $A$. novae-zelandiae have viscid caps when new and stipes that often taper and darken to black towards the base. Armillaria hinnulea has morphologically similar fruitbodies, but clamp connections are reported on subhymenial hyphae (Kile and Watling 1983; Coetzee et al. 2001). Basidiospores of A. aotearoa range larger than those described for A. hinnulea (Kile and Watling 1983). The outer hygrophanous zone on the fresh cap appears to be a consistent feature of $A$. aotearoa. Its pathogenicity to introduced and native plants is unknown.

\section{Discussion}

This paper names and formally describes A. aotearoa in order to stabilise and conclusively establish its nomenclature. Its validity as a distinct species is endorsed collectively by its morphology, its non-interfertility with other New Zealand Armillaria species in cultural pairing tests and, in particular, by published molecular sequencing data verified by the additional evidence reported here. 
In this study, the ITS sequence data clearly differentiated A. aotearoa from the other three species of Armillaria that are present in New Zealand. The ITS region of the ribosomal DNA repeat was used because the ITS has the most clearly defined gap between inter- and intraspecific variation and can therefore reliably differentiate fungal species (Schoch et al. 2012). Among the isolates sequenced, NZFS 2425 and NZFS 2426 are cultures that were derived from single basidiospores from a collection (NZFRI-M 5283) made in the central North Island in 2005, which was selected as the holotype for $A$. aotearoa. Intraspecific variation was noted by the presence of 8 sites with single nucleotide polymorphisms in the ITS- 1 and ITS- 2 of the isolates of $A$. aotearoa that were sequenced in this study. The maximum likelihood analysis of the ITS sequence data indicates that this procedure can be used to differentiate $A$. aotearoa from the other species of Armillaria present in New Zealand, including A. hinnulea which is difficult to distinguish morphologically. This confirms earlier work (Coetzee et al. 2001; Maphosa et al. 2006; Pildain et al. $2009,2010)$ and is the basis of a test to identify the New Zealand species developed by Dodd et al. (2010). Sequencing indicates that $A$. aotearoa is also distinct from other species of Armillaria found outside New Zealand in both the northern and southern hemispheres, using both the ITS and elongation factor $1-\alpha$ gene regions (Coetzee et al. 2001; Maphosa et al. 2006; Pildain et al. 2009; Ota et al. 2011).

Variation within the elongation factor $1-\alpha$ gene enables the separation of closely related Armillaria species (Ota et al. 2011). The phylogeny constructed by Maphosa et al. (2006), based on DNA sequence data from the partial elongation factor 1 - $\alpha$ gene, also clustered Armillaria sp. nov. discretely and led those authors to conclude that it is a distinct species. This species is A. aotearoa, as is shown by the $100 \%$ identity between the partial elongation factor $1-\alpha$ gene sequence of a single-spore isolate from the holotype collection and the sequences of isolates from the two collections of Armillaria sp. nov. from New Zealand that were used by Maphosa et al. (2006).

The results from the cultural haploid $\times$ diploid and haploid $\times$ haploid pairing studies support those from the DNA sequencing and indicate that $A$. aotearoa is separate from the other three New Zealand Armillaria species with which it is mutually non-interfertile (Hood 1989). By contrast, within-species pairings were interfertile for both $A$. aotearoa and, in the third test, $A$. hinnulea. This finding is unambiguous even if the technique is empirical and judgement at times subjective. Replicate pairings were mostly in agreement, although occasional failure of one of the pair to grow reduced the level of replication. Despite the distinct outcome, rates of interfertility in within-species haploid $\times$ haploid pairings were unexpectedly low, possibly due to the age of the isolates (Korhonen 1978; Qin et al. 2007). With a tetrapolar mating system, frequency of interfertility among haploid isolates from the same fruitbody should approximate to $25 \%$ for Armillaria species, and between different collections of the same species should be much greater. Pairing in the first two tests (haploid $\times$ diploid) was undertaken at a time when isolates were no more than a year old, but the third test (haploid $\times$ haploid) was conducted later when the ages of the isolates were around 10 years for some and 30 years for others. The unidentified diploid isolates (Ad34.1, Ad34.2, A223.1, Mack1985) were confirmed as A. aotearoa in the first two tests through positive interfertility with haploid isolate NZFS 4055 (A35.4), shown by sequencing to belong to this species (GenBank AF329931). These included multiple basidiospore isolates from Tongariro National Park and a rhizomorph isolate from Kaimanawa Forest Park collected in 1984, which appear to be among the first substantiated collections of $A$. aotearoa. The earliest known collection of $A$. aotearoa to date, represented by isolate NZFS 171 (identified here by sequencing), was made in June, 1984, also from Tongariro National Park.

This work has demonstrated that it will be possible to determine the precise geographic occurrence of $A$. aotearoa by using DNA-based methods. At present, its confirmed distribution is limited to the Taupo region in the North Island with records also from Mid Canterbury in the South Island. Two fruitbody collections obtained from Nothofagus forest in Mid Canterbury have been shown by sequencing to belong to this species (PDD 70486, Dodd et al. 2010; PDD 91742, ICMP 16996, GenBank GQ411506, Fukami et al. 2010, confirmed in this work; New Zealand Fungal Herbarium, Landcare Research New Zealand). Armillaria aotearoa may occur elsewhere in New Zealand. Pildain et al. (2009) reported ITS sequences for two isolates from locations somewhere in the South Island as clustering with this species (GenBank FJ711638, GenBank FJ711639). Further work is therefore required to determine whether $A$. aotearoa has a wider distribution.

\section{Conclusions}

DNA sequencing, cultural pairing and morphological examination confirm the authenticity of Armillaria aotearoa as formally named and described in this paper.

\section{Competing interests}

The authors declare that they have no competing interests.

\section{Authors' contributions}

Each author made field collections of A. aotearoa fruitbodies and isolated cultures. $\mathrm{IH}$ undertook the cultural pairing studies and examined collections macro- and microscopically. TR was responsible for the DNA sequencing analysis. The manuscript was jointly drafted by both authors. Both authors read and approved the final manuscript. 


\section{Acknowledgements}

We thank Matthew Power, Razel Blaza, Jop Sandberg, Rita Tetenburg and Pam Taylor for technical assistance and Colin Myrholm, Heather Flint, Rebecca McDougal, Tracey Bowers, Anna Caird, Tomoko Pearson and Shannon Hunter for help with DNA sequencing. Microtome sectioning was undertaken by Peter Gadgil who also provided helpful encouragement. The paper was improved by comments from two anonymous reviewers.

\section{Author details}

${ }^{1}$ New Zealand Forest Research Institute (Scion), Private Bag 3020, Rotorua 3046, New Zealand. ${ }^{2}$ Current address: Canadian Forest Service, Northern Forestry Centre, 5320-122 Street, Edmonton, AB, T6H 3S5, Canada.

Received: 25 April 2015 Accepted: 6 January 2016

Published online: 22 January 2016

\section{References}

Anderson, J. B., Korhonen, K., \& Ullrich, R. C. (1980). Relationships between European and North American biological species of Armillaria mellea. Experimental Mycology, 4, 87-95.

Coetzee, M. P. A., Wingfield, B. D., Bloomer, P., Ridley, G. S., Kile, G. A., \& Wingfield, M. J. (2001). Phylogenetic relationships of Australian and New Zealand Armillaria species. Mycologia, 93, 887-896.

Crosby, T. K., Dugdale, J. S., \& Watt, J. C. (1976). Recording specimen localities in New Zealand: an arbitrary system of areas and codes defined. New Zealand Journal of Zoology, 3, 69.

Crosby, T. K., Dugdale, J. S., \& Watt, J. C. (1998). Area codes for recording specimen localities in the New Zealand subregion. New Zealand Journal of Zoology, 25, 175-183.

Dodd, S. L., Ramsfield, T. D., \& Marshall, J. W. (2010). PCR primers to distinguish Armillaria species found in New Zealand. Australasian Plant Pathology, 39, 536-543.

Dunne, C. P., Glen, M., Tommerup, I. C., Shearer, B. L., \& Hardy, G. E. St. J. (2002). Sequence variation in the rDNA ITS of Australian Armillaria species and intraspecific variation in A. luteobubalina. Australasian Plant Pathology, 31, 241-251.

Fukami, T., Dickie, I. A., Wilkie, J. P., Paulus, B. C., Park, D., Roberts, A., et al. (2010). Assembly history dictates ecosystem functioning: evidence from wood decomposer communities. Ecology Letters, 13, 675-684. Supplementary Information Table S1.

Gadgil, P. D. (2005). Fungi of New Zealand Volume 4: Fungi on trees and shrubs in New Zealand. (Landcare Research. Fungal Diversity Research Series 16, pp. 1437). Hong Kong: Fungal Diversity Press.

Gardes, M., \& Bruns, T. D. (1993). ITS primers with enhanced specificity for basidiomycetes - application to the identification of mycorrhizae and rusts. Molecular Ecology, 2, 113-118.

Guillaumin, J.-J., \& Bérubé, J. (2005). Taxonomie et phylogénie des armillaires. In J.-J. Guillaumin (Ed.), L'armillaire et le pourridié-agaric des végétaux ligneux (pp. 43-62; Chapter 3). Paris: INRA.

Guillaumin, J-J, Anderson, JB, \& Korhonen, K. (1991). Life cycle, interfertility, and biological species. In C. G. Shaw III \& G. A. Kile (Eds.), Armillaria Root Disease. United States Department of Agriculture Forest Service Agriculture Handbook No. 691 (pp. 10-20; Chapter 2). Washington, DC: US Department of Agriculture.

Hood, I. A. (1989). Armillaria root disease in New Zealand forests. New Zealand Journal of Forestry Science, 19, 180-197.

Hood, IA. (1992). An illustrated guide to fungi on wood in New Zealand. Auckland, New Zealand: Auckland University Press in association with the Forest Research Institute.

Hood, I. A. (2012). Fungi decaying fallen stems of rimu (Dacrydium cupressinum, Podocarpaceae) in southern Westland, New Zealand. New Zealand Journal of Botany, 50, 59-69.

Hood, I. A., \& Sandberg, C. J. (1987). Occurrence of Armillaria rhizomorph populations in the soil beneath indigenous forests in the Bay of Plenty, New Zealand. New Zealand Journal of Forestry Science, 17, 83-99.

Hood, I. A., Beets, P. N., Gardner, J. F., Kimberley, M. O., Power, M. W. P., \& Ramsfield, T. D. (2008). Basidiomycete decay fungi within stems of Nothofagus windfalls in a Southern Hemisphere beech forest. Canadian Journal of Forest Research, 38, 1897-1910.

Kile, G. A. (1983). Armillaria root rot in eucalypt forests: aggravated endemic disease. Pacific Science, 37, 459-464.
Kile, G. A., \& Watling, R. (1983). Armillaria species from south-eastern Australia. Transactions of the British Mycological Society, 81, 129-140.

Kile, G. A., \& Watling, R. (1988). Identification and occurrence of Australian Armillaria species, including A. pallidula sp. nov. and comparative studies between them and non-Australian tropical and Indian Armillaria. Transactions of the British Mycological Society, 91, 305-315.

Kile, G. A., Guillaumin, J.-J., Mohammed, C., \& Watling, R. (1994). Biogeography and pathology of Armillaria. In M. Johansson \& J. Stenlid (Eds.), Proceedings of the 8th International Conference on Root and Butt Rots, Wik, Sweden and Haikko, Finland. August, 9-16, 1993 (pp. 411-436). Uppsala, Sweden: University of Agricultural Sciences.

Kimura, M. (1980). A simple method for estimating evolutionary rate of base substitutions through comparative studies of nucleotide sequences. Journal of Molecular Evolution, 16, 111-120.

Korhonen, K. (1978). Interfertility and clonal size in the Armillariella mellea complex. Karstenia, 18, 31-42.

McKenzie, E. H. C., Buchanan, P. K, \& Johnston, P. R. (2000). Checklist of fungi on Nothofagus species in New Zealand. New Zealand Journal of Botany, 38, 635-720.

Maphosa, L., Wingfield, B. D., Coetzee, M. P. A., Mwenje, E., \& Wingfield, M. J. (2006). Phylogenetic relationships among Armillaria species inferred from partial elongation factor 1-alpha DNA sequence data. Australasian Plant Pathology, 35, 513-520

Ota, Y., Kim, M.-S., Neda, H., Klopfenstein, N. B., \& Hasegawa, E. (2011). The phylogenetic position of an Armillaria species from Amami-Oshima, a subtropical island of Japan, based on elongation factor and ITS sequences. Mycoscience, 52, 53-58.

Pennycook, S. R. (2004). Bibliographic checklist of agarics, boletes and related fungi recorded from New Zealand. In E. H. C. McKenzie (Ed.), Fungi of New Zealand Volume 1: Introduction to Fungi of New Zealand. (Landcare Research. Fungal Diversity Research Series 14, pp. 165-362; Chapter 5). Hong Kong: Fungal Diversity Press.

Pildain, M. B., Coetzee, M. P. A., Rajchenberg, M., Petersen, R. H., Wingfield, M. J., \& Wingfield, B. D. (2009). Molecular phylogeny of Armillaria from the Patagonian Andes. Mycological Progress, 8, 181-194. doi:10.1007/ s11557-009-0590-8.

Pildain, M. B., Coetzee, M. P. A., Wingfield, B. D., Wingfield, M. J., \& Rajchenberg, M. (2010). Taxonomy of Armillaria in the Patagonian forests of Argentina. Mycologia, 102, 392-403. doi:10.3852/09-105.

Power, M. W. P., Ramsfield, T. D., \& Hood, I. A. (2008). Detection of Armillaria basidiospore dispersal. New Zealand Plant Protection, 61, 35-40.

Qin, G.-F., Zhao, J., \& Korhonen, K. (2007). A study in intersterility groups of Armillaria in China. Mycologia, 99, 430-441.

Ramsfield, T. D., Power, M. W. P., \& Ridley, G. S. (2008). A comparison of populations of Armillaria hinnulea in New Zealand and Australia. New Zealand Plant Protection, 61, 41-47.

Ridley, G. (1999). The Armillaria species of New Zealand (Fungi: Agaricales). Australasian Mycologist, 18, 42.

Sambrook, J., Fritsch, E. F., \& Maniatis, T. (1987). Molecular cloning - a laboratory manual. USA: Cold Spring Harbour Laboratory Press.

Schoch, C. L., Seifert, K. A., Huhndorf, S., Robert, V., Spouge, J. L., Levesque, C. A., et al. (2012). Nuclear ribosomal internal transcribed spacer (ITS) region as a universal DNA barcode marker for Fungi. Proceedings of the National Academy of Sciences (USA), 109, 6241-6246.

Segedin, B. P., \& Pennycook, S. R. (2001). A nomenclatural checklist of agarics, boletes, and related secotioid and gasteromycetous fungi recorded from New Zealand. New Zealand Journal of Botany, 39, 285-348.

Shaw III, C. G., \& Calderon, S. (1977). Impact of Armillaria root rot in plantations of Pinus radiata established on sites converted from indigenous forest. New Zealand Journal of Forestry Science, 7, 359-373.

Smith-White, J. L., Summerell, B. A., Gunn, L. V., Rinzin, C., Porter, C., \& Burgess, L. W. (2002). Molecular detection and differentiation of Australian Armillaria species. Australasian Plant Pathology, 31, 75-79.

Stevenson, G. (1964). The Agaricales of New Zealand: V. Tricholomataceae. Kew Bulletin, 19(1), 1-59.

Tamura, K., Stecher, G., Peterson, D., Filipski, A., \& Kumar, S. (2013). MEGA6: Molecular Evolutionary Genetics Analysis version 6.0. Molecular Biology and Evolution, 30, 2725-2729.

White, T. J., Bruns, T. D., Lee, S., \& Taylor, J. (1990). Amplification and direct sequencing of fungal ribosomal RNA genes for phylogenetics. In M. A. Innis, D. H. Gelfand, J. J. Sninsky, \& T. J. White (Eds.), PCR protocols. A guide to methods and applications (pp. 315-322). San Diego, CA, USA: Academic Press. 